\title{
Pedagogy of the Possessed: re-thinking the Dancer-Researcher-Performer (BPI) method in dance curricula in Brazil
}

\author{
Ana Paula Höfling \\ University of North Carolina - Greensboro, United States of America
}

\begin{abstract}
Pedagogy of the Possessed: re-thinking the Dancer-Researcher-Performer (BPI) method in dance curricula in Brazil - This paper calls into question the central tenets of the Dancer-Researcher-Performer (BPI) method taught at the Universidade Estadual de Campinas (Unicamp) in Brazil. The analysis problematizes the underlying assumption that students lack an awareness of their own Brazilianness, which they must find through BPI, and questions a choreographic methodology where students are coached to be possessed by the dance. The paper draws attention to the power imbalances inherent in BPI's co-habitation experience, where students research marginal others who are understood as the source of authentic Brazilian culture. The paper invites BPI students and teachers to reconsider the ethics of this research methodology, and to consider the possibility of choreographic research that engages both mind and body critically and consciously.
\end{abstract}

Keywords: BPI. Alterity. Dance. Choreography. Research.

RÉSUMÉ - Pédagogie des Possédés: revoir la méthode Danseur-Chercheur-Interprète (BPI) dans l'enseignement de la danse au Brésil - Cet article remet en question les principes fondamentaux de la méthode Danseur-Chercheur-Interprète (BPI), enseignée a l'Universidade Estadual de Campinas (Unicamp), au Brésil. L'analyse questionne la supposition d'un manque de prise de conscience des élèves par rapport à leur propre brésilité, laquelle ils doivent chercher à travers la BPI. Elle remet en question également une méthodologie chorégraphique où les étudiants sont entraînés à être possédés par la danse. L'article attire l'attention sur les déséquilibres de pouvoir inhérents à l'expérience de cohabitation proposée par la BPI, où les étudiants mènent une recherche sur l'autre, ceux aux marges de la société, compris comme la source d'une culture brésilienne authentique. L'article invite étudiants et enseignants de la BPI à reconsidérer l'éthique de cette méthodologie de recherche, et à envisager la possibilité d'une recherche chorégraphique qui engage à la fois l'esprit et le corps, de manière critique et consciente.

Mots-clés: BPI. Altérité. Danse. Chorégraphie. Recherche.

RESUMO - Pedagogia dos Possuídos: repensando o método Bailarino-PesquisadorIntérprete (BPI) no ensino da dança no Brasil - Este trabalho propóe um questionamento dos princípios fundamentais do método Bailarino-Pesquisador-Intérprete (BPI) ensinado na Universidade Estadual de Campinas (Unicamp), no Brasil. A análise problematiza a suposição de que os alunos não têm consciência da sua própria brasilidade, a qual eles devem buscar através do BPI, e questiona uma metodologia coreográfica na qual alunos são ensinados a serem possuidos pela dança. $\mathrm{O}$ trabalho chama a atenção ao desequilíbrio de poder inerente na experiência de co-habitar do BPI, em que alunos pesquisam outros às margens da sociedade, que são entendidos como fonte de uma autêntica cultura brasileira. $\mathrm{O}$ trabalho convida alunos e professores de BPI a reconsiderar a ética dessa metodologia de pesquisa e a considerar a possibilidade de pesquisas coreográficas que sejam capazes de engajar mente e corpo de uma forma crítica e consciente. Palavras-chave: BPI. Alteridade. Dança. Coreografia. Pesquisa. 
In this paper, I invite teachers and students of the choreographic method known as BPI to reflect upon its central tenets and practices, many of which have long been called into question in the humanities, such as the ethnographic study of impoverished and racially marked others, whose cultural practices become reduced to fodder for artistic production. I urge Brazilian dance educators to bring a critical stance to a practice that, as I propose, romanticizes and fetishizes marginal communities as a source for their student's cathartic choreographic movement explorations. I briefly compare BPI to an early twentiethcentury nationalist dance project in order to contextualize this practice historically and ideologically. I analyze in detail the three axes of BPI: Inventory of the Body, Co-habiting with the Source, and Character Structuring, focusing on the socio-political implications of these axes and questioning their place in the curriculum of a research university. I problematize the assumption that students lack an awareness of their own Brazilianness, which they must find through BPI, and question a choreographic methodology where students are coached to be possessed by the dance. Instead, I call for a conscious and critical dance pedagogy and dance research.

As a Brazilian dance scholar trained in the United States,I approach this research methodology from the outside, never having studied it; however, my knowledge of Portuguese allows me access to the vast number of texts published by BPI practitioners, not yet available in translation. I base my analysis on writings by Graziela Rodrigues, the founder of BPI, as well as theses, dissertations, and articles written by Rodrigues's disciples. ${ }^{1}$ Although I am an outsider to BPI, I bring to my analysis my own embodied Brazilianness, which includes fifteen years of ballet training in Brazil as well as twenty years of capoeira training in both Brazil and the United States. My analysis is also informed by my own lived knowledge of growing up with class and race privilege in Brazil, a country mired in deep socio-economic inequality. I offer a critical perspective and a few bibliographic resources for what I hope will be the beginning of a re-thinking of this well-intentioned choreographic research practice which, nevertheless, perpetuates colonialist, racist, and classist research practices that date back to the early twentieth century.

Throughout the 1930s and 40s, dancer and choreographer Eros Volúsia developed the bailado brasileiro, a ballet-based nationalist 
dance technique that allegedly brought together elements from Brazil's three races ${ }^{2}$ to create a Brazilian dancing body that celebrated the nationalist ideology espoused by the dictatorial regime of Getúlio Vargas known as the New State (1939-1945). Since 1937, Gustavo Capanema, Vargas's Minister of Education and Health, praised and supported Volúsia's work. In 1939, he placed Volúsia in charge of the dance classes offered through the National Theater Service in Rio de Janeiro (Volúsia, 1939, p. 43). Embodying the ideology of whitening (branqueamento) that permeated racial thought at this time in Brazil, Volúsia's bailado brasileiro employed ballet as a tool to improve the dances of Brazilian others, which she had learned through a somewhat haphazard ethnographic research practice that ranged from visiting her local macumba ${ }^{3}$ temple to watching indigenous ceremonies staged for her. As other Brazilian modernist artists of her generation, Volúsia used the dances of racialized national others as fodder for her own nationalist artistic production (Höfling, 2015a) ${ }^{4}$.

As Brazil finally returned to a democratic government in the late 1980s, fifty years later, the nationalist search for a Brazilian dancing body pioneered by Volúsia showed its tenacity in the now widely disseminated work of Graziela Rodrigues ${ }^{5}$. Rodrigues began her academic teaching career in 1987 at the newly created dance department of the Universidade Estadual de Campinas (Unicamp), one of Brazil's top research universities ${ }^{6}$. Unicamp's dance department has since grown to become one of the most respected dance departments in Brazil, offering bachelor degrees as well as master's and doctoral degrees in dance. There, Rodrigues developed a dance technique and choreographic research methodology that have become not only part of the dance curriculum at this university but, through Rodrigues's disciples, has begun to spread to other dance departments in Brazil as well. Like Volúsia's bailado brasileiro, Rodrigues's work draws from "bod[ies] located on the margins of Brazilian society" (Rodrigues, 1997, p. 27), defined as the other in the language of the method known as dancer-researcher-performer (bailarino-pesquisador-intérprete), or BPI.

The BPI method is divided into three stages (or axes): Inventory of the Body, Co-habiting with the Source, and Character Structuring (Costa; Rodrigues, 2010; Rodrigues, 1997). Through the initial Inventory of the Body, Rodrigues guides students to search for the 
Brazilianness hidden within themselves, and to discover a "singular" and "original" corporeality already present in their own bodies (Rodrigues; Tavares, 2010, p. 146). This internal search for both originality and a Brazilian corporeality, according to Rodrigues, is facilitated by contact with "marginal bodies" framed as "sources" of culture (Rodrigues, 1997, p. 27). BPI research subjects are frequently referred to as bodies rather than people, and the research purportedly happens primarily through the body, bypassing reason, in empathic and affective exchanges that take place during the Co-habiting with the Source axis (Costa; Rodrigues, 2010, p. 26). Rodrigues's students spend time (ranging from a few days to over a year) in often rural and always impoverished communities, places thought to harbor both "vitality" and a genuine Brazilian corporeality (Costa; Rodrigues, 2010, p. 27). According to Rodrigues, these communities are sites of cultural resilience, where rituals and festivities remain alive in the bodies of "guardians of the model of popular culture [...], simple and humble people who have the power to transform a hard and painful everyday into a celebration of life" (Rodrigues, 1997, p. 125). Upon their return to the university, students begin the process of Character Structuring, a highly personal and often emotional choreographic search for a character - a kind of alter ego that contains aspects of the people with whom the student $c o$-habited in the field. This character allegedly allows students to move freely, in ways previously unknown to them, where inhibitions and blockages give way to movement that is both original and national. In the next three sections, I describe and analyze each axis of BPI in detail.

\section{Taking Inventory of the Body (Inventário do Corpo), learning Symbolic Anatomy (Anatomia Simbólica) and Physical Structure (Estrutura Física)}

BPI field research is preceded and followed by movement training and personal movement investigation in the studio. Students begin by taking a course titled Dança Brasileira (Dance of Brazil), where they learn movement principles allegedly shared by all Brazilian dances ${ }^{7}$. These classes are based on Symbolic Anatomy principles, a movement technique derived from Rodrigues's observations of Brazilian "popular"8 dances in her "search for [a] Brazilian body" (Rodrigues, 1997, p. 27-28; p. 43-55). Rodrigues identified what she 
interpreted as commonalities to all Brazilian popular movement forms she observed (most of them Afro-diaporic), and synthesized these elements into a kind of pan-Brazilian dance technique intended to awaken a uniquely Brazilian corporeality in her students.

As I read about her principles of Symbolic Anatomy, my own body identified immediately with these principles, based on a pulledup, mast-like vertical body, whose lower half is rooted into the earth through the feet while the upper half reaches upward to the sky; the coccyx and sacrum send energy downwards and the sternum is the place where emotions reside (Rodrigues, 1997, p. 43-55). My identification, however, surely comes from my extensive training in ballet, modern, and postmodern dance techniques rather than from my own Brazilianness. Reading about a musculature that works in spirals immediately took me back to my Graham technique classes in college. Tracing figure eights with the pelvis (which Rodrigues calls movimento do infinito), a movement I have performed in dance class warm-ups in various styles, is presented as derived from the side-to-side hip movement present in many Brazilian dance forms - a movement Rodrigues declares to be "overrated" (Rodrigues, 1997, p. 50) ${ }^{9}$. Rodrigues's technique stresses balance, verticality, body unity, and harmony -principles very familiar to anyone trained in ballet. Eros Volúsia, in her quest to bring Brazil's "folk-dances" to high art stages, similarly used ballet principles to smooth out movements that were perceived to be unrefined, such as the "exaggerated hip movement" of Afro-Brazilian dances (Volúsia, 1939, p. 51).

The BPI method, lauded as "innovative" (Márcio Souza's preface in Rodrigues, 1997; Melchert, 2007, p. 9), employs several unacknowledged principles from ballet, modern dance, and from a number of somatic-based postmodern dance techniques. Touted as a way of "liberating" the body from both style and technique ${ }^{\mathbf{1 0}}$ (Rodrigues 1997, p. 21), BPI training nevertheless includes several aspects central to ballet and modern/postmodern dance, thus reflecting Rodrigues's own early dance training in these dance forms ${ }^{11}$. Rodrigues states that her search for a new way of engaging with dance was brought about by her dissatisfaction with her own dance training, "marked by the rigor of discipline" (Rodrigues, 1997, p. 17). Ironically, BPI not only reproduces some of the core values and discipline of ballet, it also reproduces modern dance's narrative 
of rebellion and rejection of what came before, valuing individual originality and self-expression.

As to the pan-Brazilianness of Symbolic Anatomy principles, my assessment is based on about twenty years of training in capoeira, a movement form that allegedly contributes to BPI vocabulary. In my own capoeira practice, I had to unlearn the verticality, unity, and harmony instilled in me through ballet, precisely the same principles taught in BPI. Although I am not an expert in all dances of Brazil, nor do I know anyone who is, I do not believe that verticality, balance, and body unity are at the core, or even relevant, in most of them. They certainly are not in capoeira, where the body is slightly inclined forward, soft and pliable, and always off-balance (constantly losing and re-gaining balance) - never vertical, much less rooted or reaching for the sky.

These Symbolic Anatomy principles are at the core of what is referred to as Physical Structure, a way of organizing the body allegedly common to all Brazilian movement forms. Although derived from a uniquely Brazilian corporeality, these principles are understood as archetypal (in Carl Jung's use of the term), going beyond their regional and national referents (Rodrigues, 1997, p. 43; 2003, p. 86). Under the umbrella of Physical Structure training, the BPI student is guided to explore her body image. Based on the theories of body image developed by Austrian psychoanalytic theorist Paul Schilder, a student of Sigmund Freud, BPI's body image is explored during the initial phase of BPI research called Inventory of the Body.

In one-on-one studio sessions with a certified BPI director, the student is guided to take inventory of her body and dive into her "corporeal biography" (Nagai, 2012, p. 4). In this axis of the methodology, the dancer-researcher-performer "is constantly stimulated by the BPI director to describe the flow of images, emotions and sensations that happens with the movement" (Nagai, 2012, p. 8). Often students are encouraged to search for (or remember) people in their own families (grandparents, great-grandparents, uncles and aunts) who may have engaged in "popular manifestations," or people who may have belonged to "other socio-economic strata" (Melchert, 2008 , p. 3). The search for the other that will intensify in the axis Co-habiting with the Source starts here, but here this other is connected to, and thus authorizes, this othered self ${ }^{2}$. 
During their bodily inventory, students are not, however, invited to reflect on their own prior dance training, non-dance movement practices such as sports, or quotidian life experiences. Instead, the director guides an inventory focused on a distant past, on the dancer's roots, both familial and cultural, and her/his emotional connections to these roots; students are asked to uncover what is referred to as their "veiled culture." The goal is to achieve "a body at peace with its origins, with its flow of emotion, and present in the ritual actions of the celebration of life" (Rodrigues, 2003, p. 87). The movement material is understood to flow from the dancer's unconscious - it is received by the body. The images that accompany the movement are verbally communicated to the director during these improvisation sessions. The director then selects and shapes these images and emotions as well as their accompanying movement, acting as a dramaturge. There is a clear agenda of affirmation and transformation in these studio sessions: the director selects the acceptable emotional content to be carried over into future sessions - "only [emotional] content of vitality, of affirmation of life will be selected to be "danced"' (Nagai, 2012, p. 8). The assumption that students are not already at peace with their cultural and familial origins, and need several one-on-one movement sessions based on unconscious imagery to "affirm" and celebrate life, pathologizes students and places the director in the role of psychotherapist. While these movement sessions may be appropriate in a therapeutic context, the place of this medicalized pedagogy in the curriculum of a research university must be re-examined.

\section{Co-habiting with the Source (Co-babitar com a Fonte): living with marginal bodies and exercising alterity}

For at least the past thirty years, scholars working in the fields of anthropology, sociology, cultural studies, performance studies, and dance studies, have written extensively about the problematic nature of researching the other (See Clifford, 1988; Appadurai, 1989; Narayan, 1993; Ness, 1996; Buckland, 2006; O'Shea 2010; Madison, 2012). Since the 1980s, ethnography as a research methodology has come under scrutiny - its purported objectivity, its colonial legacy, the complex relationships between observer/observed often glossed over in the final document, and the uneven encounters and exchanges that take place through ethnographic participant-observation. 
BPI's second axis, Co-habiting with the Source, shares many similarities with ethnographic research: students choose a research site and live for varying periods of time with the source community; they keep a field journal and their research often includes video and audio recordings (Melchert, 2007; Nagai, 2012). But because research is framed as a co-habitation where both parties empathically share embodied knowledge and develop a relationship based on love (Nagai, 2012, p. 53; Rodrigues, 2003, p. 119-120), presumably with no agenda, students are not trained in ethnographic research. Informed consent does not seem to be required in BPI research BPI students Melchert, Nagai, and Valardão make no mention of informed consent in otherwise detailed accounts of their preparation for field research (Melchert, 2007; Nagai, 2012; Valardão, 2014). In fact, deception of research subjects seems to be an accepted practice: in her first co-habitation experience, Rodrigues did not disclose herself as a researcher during her visits to an employment agency over three months of research, when she befriended and interviewed domestic workers who spent time at the agency waiting for work. Rodrigues recounts:

I started to frequent the agency, looking to stay as undetected as possible [...]. These were three months of daily interactions, until the day when at the employment agency a fine lady, as if choosing a new outfit, scanned the line of women from head to toe and pointed at me [saying] 'I choose this one'. Thus ended the main phase of my field research (Rodrigues, 1997, p. 19).

It is interesting that Rodrigues did not accept the job offer, an opportunity that would have surely provided her with an embodied understanding of the back-breaking domestic work that her research subjects performed on a daily basis. The socio-economic disparity that becomes evident in this encounter - the researcher who has the resources to spend three months pretending to wait for a job offer, while her research subjects actually depend on low paying, physically demanding work as house maids to feed their families - is never addressed by Rodrigues, and neither are the ethics of her choice not to disclose herself as a researcher.

However, when Rodrigues and her graduate students undertake research using college students as research subjects, informed consent forms are signed and questionnaires are vetted by academic boards 
on research with human subjects (Rodrigues [2003] and Melchert [2010] analyze questionnaires and interviews with Unicamp students). The domestic workers who unknowingly participated in Rodrigues's research, whose life experiences were later synthesized in her choreography, remain an undifferentiated group of others who were not even aware of their participation in this research project.

The co-habiting experience is framed as an exchange between the self and the other - similar to the exchange that is at the core of ethnographic experience, where knowledge, as noted by James Clifford, is produced from "an intense, intersubjective engagement" (Clifford, 1988, p. 24). Several scholars whose work includes ethnographic participant-observation have wrestled with the problems of translating field experiences - subjective, dialogic, empathic, and "shot through with power relations" (Clifford, 1988, p. 23) - into a written document. In her now seminal article "Dancing in the field: notes from memory," dance scholar Sally Ann Ness presents the reader with a text that "fails to shine as a polished product" and "says 'no' to the document"; instead, she publishes writing that is "subjective, spontaneous, private, unpublishable," and does so "way too soon" (Ness, 1996, p. 133). In her book Sharing the dance: contact improvisation and American culture, Cynthia Novack breaks with the convention of studying the other and instead chooses to focus on a movement practice that is not only close to home, but one where she is an a insider (Novack, 1990). In addition to Ness and Novack, other dance scholars have problematized the self studying the other paradigm, the authority of the ethnographer,and the objectivity of the final written document, such as Cindy Garcia (2013), Priya Srinivasan (2012), and Marta Savigliano (2003), to name a few.

Since the final product of BPI research is danced rather than written - solo performances that partially fulfill the requirements for master's or doctoral degrees in dance - this research method has the potential of further subverting and de-stabilizing ethnographic authority and exposing the impossibility of objectivity in ethnographic research. By dancing their research findings, BPI researchers have the potential to not only make dances that deal with their own subjective experiences in the field, but dances that offer a critical stance and raise awareness about the everyday lives of their research subjects, who often live in remote or at-risk communities, where 
social inequality is palpable (as mentioned before, socio-economic marginality is a requirement in the selection of a research site for BPI research). However, the final product of this research centers on the self rather than the other: "[...] by bringing awareness to contact with 'the other', the dancer is able to bring awareness to himself [sic]" (Rodrigues; Tavares, 2010, p. 146). After spending time in the source community, BPI student-researchers return home to explore, through dance, how the experience in the field has transformed themselves both physically and psychologically. The final written documents that accompany these choreographic explorations include very little in terms of historical contextualization, description, or critical analysis of the field experience itself ${ }^{13}$ (Nagai, 2012, p. 5769; Melchert, 2010, p. 32-46), and instead focus on the process of character incorporation and development that happens in the studio following the field research (discussed in more detail below).

The fact that dancer-researcher-performers are arguably native ethnographers - Brazilians engaging in research in Brazil - also has the potential of disrupting the neat selflother binary that defined early ethnographic research (see Narayan, 1993 and Appadurai, 1989 for a discussion of the native category). However, BPI research in fact reinforces this dichotomy by prescribing that students must interact and live (co-habit) with "marginal bodies," "men of the people" defined as "the other" (Melchert, 2007, p. 8-10). In what Melchert describes as an "exercise of alterity," BPI researchers are able to "see the other" (Melchert, 2007, p. 8). Student-researchers are positioned as mobile observers - "they are the movers, the seers, the knowers" (Appadurai, 1989, p. 37) - while the source communities are reduced to static repositories of culture, living museums where people retain and transmit culture (Rodrigues, 1997, p. 30), but are implicitly incapable of the kind of original, unique, and contemporary choreographic innovation that will later take place in the BPI studio.

BPI research subjects are conceptualized, unproblematically, as both other and static source - sources of a purportedly authentic Brazilian culture, to be tapped and embodied by the erudite studentresearcher. Melchert explains that "the body, found in the field research, is a marginal body that possesses a strong sense of survival and resilience" (Melchert, 2007, p. 8). These "resilient" others are further defined by Rodrigues as "keepers" and "guardians" 
of Brazilian culture (Rodrigues, 1997, p. 30; p. 125). Rodrigues's conception of an other who keeps or guards national culture in his/her body echoes antiquated ideas developed in Brazilian folklore studies during the mid twentieth-century; folklorists such as Renato Almeida analyzed the cultural practices of folklore bearers, people defined as other to an erudite self comprised of intellectuals and artists (Höfling, 2015b, p. 99). Rodrigues uses the term "popular manifestations" (manifestaçôes populares) to refer to the festivals and rituals her students are encouraged to observe (Rodrigues, 1997, p. 21). Here, the adjective popular refers to the people, a group that is often racially and always socio-economically other to the BPI artist/intellectual. In the 1950 s, folklorists wrote about the people as a separate category of human beings who passively carried folk knowledge. In BPI, the nomenclature has changed without any change in ideology: the people and its adjective popular are used in euphemistic ways to perpetuate the same hierarchies used by folklorists in the mid twentieth century.

It is important to acknowledge that these co-habitation field experiences are well intentioned: Rodrigues is aware, although this is never explicitly stated, that most of her students come from privileged socio-economic backgrounds, and for them to go live with people who may not have electricity, running water, or enough to eat is surely an unforgettable, life-altering experience. Costa and Rodrigues (2010, p. 26) and Melchert (2007, p. 7) speak of a "feeling of strangeness" (estranhamento) in the first encounter and the need to shed prejudices and pre-conceptions on both sides. Surely these field experiences are transformational for the students; in the master's thesis and doctoral dissertations I consulted, it is clear that BPI students develop relationships based on respect and admiration toward the people in the source community. It is unclear, however, how BPI research subjects benefit from these projects, and it is also unclear whether the empathy, affection, and love that BPI co-habitation allegedly elicits are, in fact, reciprocal. The glaring social inequality between the people living on the margins and the college students who come to study them surely gets in the way of this alleged reciprocity.

While in the field, Rodrigues's students are taught not to focus on the socio-economic inequalities they witness. Instead, BPI re-frames inequality and poverty as a romanticized resilience: "the daily struggle for existence and the resilience contained inside these 
bodies endow them with peculiar qualities that become evident in their rituals and festivities" (Costa; Rodrigues, 2010, p. 26). These "resilient" people may "suffer many challenges, but overcome [their] own disgrace" (Rodrigues, 1997, p. 127). Discussing her research among female rural day laborers (bóias-frias), Rodrigues states that, "even in the midst of suffering, these women don't lose their sensibility to continue living life with pleasure" (Rodrigues, 1997, p. 126). BPI ideology reproduces the trope of the poor but happy person, widely discussed in tourism studies (see Freire-Medeiros, 2013) ${ }^{14}$. This trope frames the poor person as a kind of "noble savage living in harmony with nature" who possesses "irrepressible spontaneity and authenticity" (Pasqualino, 2008,p. 345); it limits social mobility and helps maintain the status quo (Cavalcante, 2014, p. 49). Not only does BPI research not include a social justice agenda, it in fact relies on the continuation of social injustice, as BPI students (in their majority white, urban, and middle class) seek in these poor but happy communities the Brazilianness and vitality they are presumed to lack.

\section{Incorporation of the Character (Incorporaçáo do Personagem) and Character Structuring (Estruturaçáo do Personagem)}

After having trained in the allegedly pan-Brazilian Symbolic Anatomy principles of BPI technique and taken inventory of the veiled Brazilianness of their bodies, students return from the field ready for their post-field research studio sessions. These are similar one-on-one sessions with a director, but have the intent of opening up the dancer's body to welcome the character (personagem) they will later develop for a culminating solo performance (in partial fulfillment of their degree). This character is incorporated in the same way an Afro-Brazilian deity incorporates itself into the body of a devotee, in a process akin to possession. Rodrigues explains that the process of character incorporation in BPI is inspired by her research into "Brazilian rituals" - and mentions examples of trance and possession in the Afro-Brazilian religious practices of candomble and umbanda (Rodrigues, 1997, p. 81). She directly compares character incorporation with religious possession: "The 'horse' does not choose what he will incorporate. It is a truth that does not depend on the taste of the person. The person lets go of his self-image to receive in his body whatever is needed, necessary" (Rodrigues, 1997, p. 84). 
Incorporation is triggered by several studio sessions (called laboratory sessions) where the director stimulates a synthesis of the co-habitation experience in the dancer's body through verbal prompts that lead the dancer to construct a landscape (paisagem) that will facilitate the birth of the character.

The director begins shaping the movement material that allegedly emerges from the dancer's unconscious in these sessions, "without prioritizing cognition" (Rodrigues, 2003, p. 126). Archetype-like bodies emerge from these sessions, such as the camouflaged body, the festive body (Rodrigues, 2003, p. 127), the body-vessel, the gypsy body, and the jaguar body (Nagai, 2012, p. 10-13). The character is "incorporated" at the "moment of synthesis," where all images and feelings come together to create a character that reveals, in fact screams, her first name through the dancer/horse (Rodrigues 2003, p. 127). As the title of Rodrigues's chapter on incorporation indicates, the dancer "dances the name" of the character (Rodrigues, 2003, p. 121). Ironically, while the character has a name, the marginal people who were the source for the creation of a characterare are never named. They remain anonymous sources, marginal "men (and women) of the people" (Melchert 2007, p. 10) fused into a character who is unique, embodied by a college student who, likewise, affirms her uniqueness in the world. The moment of incorporation is always highly emotionally charged - this is the moment of catharsis. One of Rodrigues's students recounts her experience:

[The character] started taking shape in my body and I wouldn't stop dancing. I couldn't stop, my body was on fire inside, and despite being conscious, it was difficult to stop. So I was asked [by the director] to spin and I spun and spun until I stopped and suddenly started crying, which scared me, because I didn't recognize that voice. I curled up, my body writhed and I cried a lot. In other [sessions], since that day, [the character] has always come (Rodrigues, 2003, p. 141).

In this passage it is clear that the therapeutic and cathartic aspect of these laboratory sessions is central to the BPI process, and the director plays an active role both in bringing about these cathartic experiences and in the later structuring of the character during the second part of this last axis of BPI.

In addition to providing verbal cues and shaping both the conscious and the unconscious movement exploration, the director 
makes sure that the content of these final performances is in line with BPI's narrative of celebration and affirmation. A character that may bring awareness to the social, racial, or gender injustices observed in the field is not only discouraged, it is dismissed and replaced by a character that celebrates life. One of Rodrigues's master's students began developing a character named Justina, but the student reported feeling a recurring resistance to her incorporation. During class, Rodrigues asked the student about the meaning of the name Justina, and the answer was that it came from the word justice, which the student interpreted as a personal sense of justice, or injustice, and the desire for revenge. Rodrigues promptly asked the student to change the name of the character, or rather, to "yield to another name." In her master's thesis, the student explains: "Justina-justice-vengeance should be left behind so that I could proceed in the direction of a life force. [...] The name Justina referred to the somber side of the character. [...] This is why I had to look for a new name, [one] that could affirm its luminous side, allowing me to let go of the search for justice" (Melchert, 2007, p. 129).

If one were to take the model of possession and incorporation literally, which Rodrigues and her students seem to do, then why not listen to Justina, who may be clamoring for justice for her marginal community? Could Justina perhaps be angry that she does not have access to the same doctors, dentists, schools, libraries, grocery stores, and university education as her horse? Could Justina be upset that she is an amalgam of real people who remain voiceless after co-habiting with (primarily) white, middle-class college students? Rodrigues, who (re)directs the tone of her students' laboratory explorations, chose to silence rather than give voice to Justina, whose anger and potential rebelliousness was not welcome in BPI. Justina was replaced by Juventina (who, not surprisingly, symbolized life and rebirth) after the student was asked to read about Inana, a Sumerian goddess discussed in a Jungian psychology book (Perera, 1985) often recommended by Rodrigues. Predictably, Inana exemplifies heteronormative woman-centered affirmation, emphasizing connections to nature, self-awareness, healing, and an egalitarian relationship between man and woman (Melchert, 2007, p. 132-133). Inana brings order to BPI's narrative of self-discovery, healing, and transformation.

In her discussion of the political and social implications of staging fieldwork data, performance studies scholar D. Soyini 
Madison proposes guiding questions a researcher-performer should consider in translating from the field to the stage:

By what definable material means will the subjects themselves benefit from the performance? How can the performance contribute to a more enlightened and involved citizenship that will disturb systems and processes that limit freedoms and possibilities? In what ways will the performers probe questions of identity, representation, and fairness to enrich their own subjectivity, cultural politics, and art?" (Madison, 2012, p. 91).

The character Justina, had it been developed, might have allowed this student to engage with some of Madison's questions. Framing BPI's research subjects as resilient, poor but happy people allows BPI choreographers to focus on their own transformation and affirmation as unique artists rather than on the injustices witnessed in the field; as a result, these performances do not interrogate the causes of social inequality, nor do they contribute to creating "a more enlightened and involved citizenship".

In addition to Madison's book, Critical ethnography: method, ethics and performance (2012), many excellent texts have been published by scholars investigating performance, choreography, ethnography, and the empathic experience BPI students seek in the field. In addition to the sources listed throughout this essay, the chapter Ethnography and Choreography in Sally Ness' (1992) Body, movement, and culture: kinesthetic and visual symbolism in a Philippine community, and Susan Foster's (2011) Choreographing empathy: kinesthesia in performance seem particularly relevant to the type of research BPI students engage in. There is no shortage of literature in dance and performance studies that could guide BPI students to engage critically and ethically with their research. Freudian, Schilderian, and Jungian psychoanalytic theories may not offer the best theoretical foundation for engaging in choreographic research.

\section{Concluding Thoughts: towards conscious and critical approaches to dance research in Brazil}

While the search for an authentic embodied Brazilianness in the movement practices of the folk was congruent with the ideology of a nationalist Brazil during the first half of the twentieth century, this same search seems anachronistic a century later. As can be seen 
in the student testimonials transcribed in Rodrigues's 2003 doctoral dissertation, BPI has cathartic and therapeutic potential. Could BPI be reframed in the curriculum as a therapeutic practice, making room both for dance classes in specific Brazilian dance forms taught by experts and for courses in performance ethnography and critical dance studies? This reformulation would prepare students to engage critically and respectfully with people who practice popular Brazilian dance forms, acknowledging their agency in their dance practices rather than framing them as static repositories of popular culture at the service of the student's artistic creativity. Students might then be equipped to question the classist assumption that the people (o povo), i.e. those living in poverty, possess a natural resilience that allows them to "overcome their own disgrace" (Rodrigues, 1997, p. 127).

Choreographic output resulting from field research experiences in disadvantaged communities, whether framed as co-habitation or ethnographic research, must reflect ethical research practices and must include a social justice component. The socio-economic marginality of the group studied should not be romanticized and transformed into a source of celebration of life and vitality; instead, such marginality should be problematized, questioned, given visibility, contextualized historically and politically, analyzed in terms of racial and gender exclusion and inclusion, with the goal of lessening or, in an ideal world, eliminating marginality altogether.

In addition, I believe we must question a pedagogical model that assumes college dance students need emotional and psychological transformation. What are the implications of assuming the students are psychologically broken when the vast majority of BPI students are female? Surely we as educators would like to transform our students, but the role of the university, especially in the arts and humanities, is to produce graduates capable of engaging critically with the world around them. In dance departments, this critical engagement not only could but should happen through the body, a body capable of a lot more than responding to the dancer's unconscious and serving as a horse or medium who is possessed by a dance shaped by the director/professor. Conscious, critical thinking is not antithetical, but rather central, to embodied research. 


\section{(and

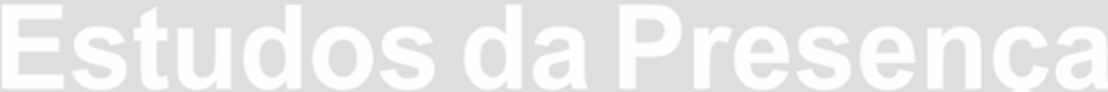

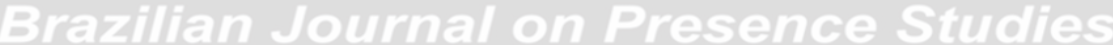

\section{Notes}

${ }^{1}$ To my knowledge, all publications on BPI to date are authored by Rodrigues and her disciples (Rodrigues herself often appears as a co-author in papers written by her former students), and these are descriptive reflections on the method and/or accounts of research and choreographic experiences employing BPI; I am unaware of any texts that approach BPI critically.

2 The notion that Brazil's racial and cultural make-up was a product of the mixture of three "races" - "the Portuguese, the Indian and the Negro", in the language of the time - derives from ideas disseminated by the writings of social Darwinist literary critic Silvio Romero during the late nineteenth century.

${ }^{3}$ Macumba is one of many iterations of Afro-Brazilian religious practice. For a detailed analysis the continuum of Afro-Brazilian religions, see Stefania Capone's (2010) Searching for Africa in Brazil.

${ }^{4}$ I have presented on the work of Eros Volúsia at the Society of Dance History Scholars and Congress on Research in Dance joint conference in Athens (June 2015) and at the $23^{\text {rd }}$ International Congress of the Latin American Studies Association in San Juan, Puerto Rico (May 2015). I analyze Eros Volúsia's bailado brasileiro in relationship to the construction of race and nation in Brazil in my forthcoming article titled "Eros Volúsia's choreographies of Brazilian mestiçagem."

${ }^{5}$ Rodrigues does not claim any connection to Volúsia or bailado brasileiro - the parallel between the two is part of my analysis and not due to an actual continuity of training or lineage between these two educators.

${ }^{6}$ The first dance department in a Brazilian university was founded at the Universidade Federal da Bahia (UFBA) in 1956 by Polish expressionist dancer Yanka Rudzka. Rudzka was intrigued by Afro-Brazilian culture and many of her works draw on Afro-Brazilian practices such as candomblé. Rudzka's interest in Brazilian culture is relevant in light of Rodrigues's focus on dances of Brazil as a source for her technique and choreographic research methodology. However, Rudzka never attempted to create a pan-Brazilian dance technique, as did Rodrigues. For a brief history of the dance program at UFBA and theatrical dance in Salvador, see Luana Vilaronga Cunha de Araújo's (2008) master's thesis, Estratégias poéticas em tempos de ditadura: a experiência do grupo experimental de dança de Salvador, $B A$. To my knowledge, a history of the dance program at Unicamp (Brazil's second dance department, created in 1985) has not yet been written.

${ }^{7}$ In the early 2000s I became interested in learning more about dance programs in universities in Brazil, and I visited the dance department at Unicamp. During my visit, I was allowed to observe a studio dance class called Brazilian Dance. The class, taught by a ballet-trained graduate student, seemed to combine elements from several Afro-Brazilian movement practices without exploring any one form in-depth. I was puzzled by this generic approach to dances of Brazil in a place where specialists in each of these forms would be easy to find and might be better suited to teach students the specificities of each dance practice. 


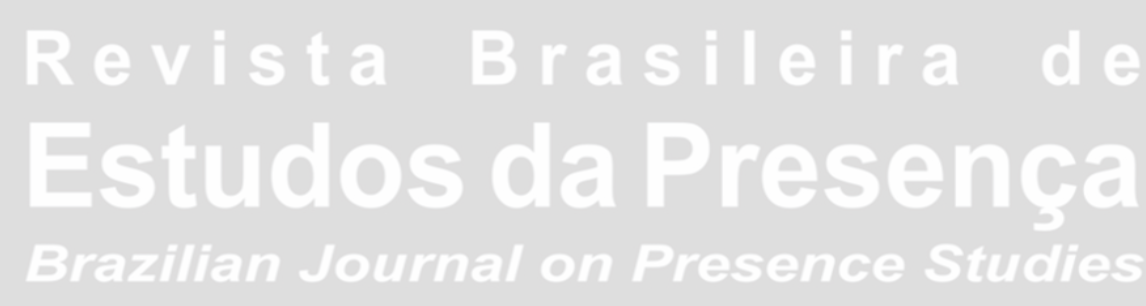

E-ISSN 2237-266

${ }^{8}$ The adjective popular in Portuguese means of the people, which literally refers to all people, but in practice the term is used with a clear class connotation and refers to a group of people conceptualized in opposition to a socio-economic and intellectual elite - in other words, popular refers to poor, uneducated people.

9 The author uses the word inflacionado (inflated, used in the same way as when describing monetary inflation) to refer to what she sees as an excessive emphasis on hip movement in descriptions of Brazilian dances.

${ }^{10}$ The statement that BPI is a way of liberating the body from technique reflects a lack of engagement with one of the foundational texts in sociology, anthropology, dance studies, and studies of the body: Marcel Mauss's seminal article "Techniques of the body," first published in 1934.

${ }^{11}$ Rodrigues does not discuss her previous dance training in detail in her book (Rodrigues, 1997). Her curriculum Lattes, available online, reveals training in jazz dance, ballet (listed as dança clássica), modern dance, and "expressive movement." One of Rodrigues's students, Paula Caruso Teixeira, wrote her PhD dissertation on the early career of her advisor and the origins of BPI: "A história das origens da criação do método Bailarino-PesquisadorIntérprete (BPI) e do seu desenvolvimento no primeiro percurso da sua criadora (19701987)". Unfortunately, the dissertation is currently under embargo and was not available for consultation. It is my hope that this essay sparks a discussion that includes the voices of BPI teachers, students, and historians, who no doubt have access to material that was not accessible to me at the time of this writing.

${ }^{12}$ I am grateful to Patricia de Santana Pinho for suggesting the idea of an othered self in relationship to BPI research.

${ }^{13}$ Nagai devotes twelve pages out of 165 pages and Melchert devotes fourteen out of 158 pages to her field experiences.

${ }^{14}$ Recent research on poverty tourism in Brazil has brought to our attention the problems inherent in framing those who live in poverty as people who are "cheerful" despite their socio-economic status and living conditions (see Freire-Medeiros, 2013, p. 159-160).

\section{References}

APPADURAI, Arjun. Putting hierarchy in its place. Cultural Anthropology, v. 3, n. 1, p. 36-49, 1989. ARAUJO, Luana Vilaronga Cunha de. Estratégias Poéticas em Tempos de Ditadura: a experiência do grupo experimental de dança de Salvador, BA. Dissertação (Mestrado) Escola de Teatro e Escola de Dança, Universidade Federal da Bahia, 2008.

BUCKLAND, Theresa. Dancing from Past to Present: nation, culture, identities. Madison: University of Wisconsin Press, 2006.

CAPONE, Stefania. Searching for Africa in Brazil: Power and tradition in candomblé. Durham: Duke University Press, 2010.

CAVALCANTE, Andre. You better 'redneckognize'!: deploying the discourses of realness, 
social defiance, and happiness to defend Here Comes Honey Boo Boo on Facebook. In: SLADE, Alison F.; NARRO, Amber J.; BUCHANAN, Burton P. (Ed.). Reality Television: oddities of culture. Lanham, MD: Lexington Books, 2014. P. 39-58.

CLIFFORD, James. The Predicament of Culture: twentieth-century ethnography, literature, and art. Cambridge: Harvard University Press, 1988.

COSTA, Elisa Massariolli da; RODRIGUES, Graziela. A Experiência do Método BPI na Criação em Dança: o corpo como lugar de encontro. Moringa Teatro e Dança, v. 1, n. 1, p. 25-33, 2010.

FOSTER, Susan Leigh. Choreographing Empathy: kinesthesia in performance. London and New York: Routledge, 2011.

FREIRE, Paulo. Pedagogy of the Oppressed. New York: Continuum International Publishing Group, 2011.

FREIRE-MEDEIROS, Bianca. Touring Poverty. London and New York: Routledge, 2013. GARCIA, Cindy. Salsa Crossings: dancing latinidad in Los Angeles. Durham and London: Duke University Press, 2013.

HÖFLING, Ana Paula. Dancing slavery, mestiçagem, and Brazilian national identity in Rio de Janeiro's Municipal Theater in 1943. In: INTERNATIONAL CONGRESS OF THE LATIN AMERICAN STUDIES ASSOCIATION, 33, 2015, San Juan. Paper... San Juan, Puerto Rico, 2015a.

HÖFLING, Ana Paula. Staging capoeira, samba, maculelê and candomblé: Viva Bahia's choreographies of Afro-Brazilian folklore for the global stage. In: ALBUQUERQUE, Severino; SANCHEZ, Kathryn (Ed.). Performing Brazil: essays in culture, identity and the performing arts. Madison: University of Wisconsin Press, 2015b. P. 98-125.

MADISON, D. Soyini. Critical Ethnography: method, ethics and performance. Los Angeles and London: Sage Publications, 2012.

MELCHERT, Ana Carolina Lopes. O Desate Criativo: estruturação da personagem a partir do método BPI (bailarino-pesquisador-intérprete). 2007. Dissertação (Mestrado em Artes) - Instituto de Artes, Universidade Estadual de Campinas, 2007.

MELCHERT, Ana Carolina Lopes. Manifestaçóes da cultura no corpo através do eixo Invertário no Corpo do BPI. In: REUNIÃO CIENTÍFICA DE PESQUISA EM ARTES CÊNICAS, 5, 2008, Belo Horizonte. Anais... Belo Horizonte, 2008.

MELCHERT, Ana Carolina Lopes. A Descoberta da Cultura Velada e dos Gestos Vitais: um aprofundamento no eixo inventário no corpo do método BPI (bailarino-pesquisador-intérprete). 2010. Tese (Doutorado em Artes) - Instituto de Artes, Universidade Estadual de Campinas, 2010.

NAGAI, Angela Mayumi. Quem dança em mim? Uma relação personagem-intérprete no método BPI (bailarino-pesquisador-intérprete). 2012. Tese (Doutorado) - Instituto de Artes, Universidade Estadual de Campinas, 2012.

NARAYAN, Kirin. How native is a 'native' anthropologist? American Anthropologist, v. 95, n. 3, p. 671-686, 1993. 
NESS, Sally Ann. Body, Movement, and Culture: kinesthetic and visual symbolism in a Philippine community. Philadelphia: University of Pennsylvania Press, 1992.

NESS, Sally Ann. Dancing in the field: notes from memory. In: FOSTER, Susan (Ed.). Corporealities: dancing knowledge, culture and power. London and New York: Routledge, 1996. P. 133-158.

NOVACK, Cynthia. Sharing the Dance: contact improvisation and American culture. Madison: University of Wisconsin Press, 1990.

O'SHEA, Janet. Roots/routes of dance studies. In: CARTER, Alexandra; O'SHEA, Janet (Ed.). The Routedge Dance Studies Reader. 2. ed. New York and Oxon: Routledge, 2010.

PASQUALINO, Caterina. The gypsies, poor but happy. Third text, v. 22, n. 3, p. $337-$ 345, 2008.

PERERA, Sylvia B. Caminho para Iniciação Feminina. São Paulo: Paulus Editora, 1985. RODRIGUES, Graziela. Bailarino, Pesquisador, Intérprete: processo de formação. Rio de Janeiro: FUNARTE, 1997.

RODRIGUES, Graziela. O Método BPI (bailarino-pesquisador-intérprete) e o Desenvolvimento da Imagem Corporal: reflexóes que consideram o discurso de bailarinas que vivenciaram um processo criativo baseado neste método. Tese (Doutorado em Artes) - Instituto de Artes, Universidade Estadual de Campinas, 2003.

RODRIGUES, Graziela; TAVARES, M. da Consolação G.C.F. Mudanças na Imagem Corporal de Bailarinas que Vivenciaram o Método BPI (bailarino-pesquisador-intérprete). Repertório: teatro e dança, Ano 13, n. 14, p. 145-152, 2010.

SAVIGLIANO, Marta Elena. Angora Matta: fatal acts of north-south translation. Middletown: Wesleyan University Press, 2003.

SRINIVASAN, Priya. Sweating Saris: Indian dance as transnational labor. Philadelphia: Temple University Press, 2012.

TEIXEIRA, Paula Caruso. A História das Origens da Criação do Método Bailarino-Pesquisador-Intérprete (BPI) e do seu Desenvolvimento no Primeiro Percurso da sua Criadora (1970-1987). 2014. Tese (Doutorado em Artes) - Instituto de Artes, Universidade Estadual de Campinas, 2014.

VALARDÃO, Sara Dias. Relaçóes de Risco: um processo criativo com adolescentes em situação de vulnerabilidade social a partir do método BPI (bailarino-pesquisador-intérprete). 2014. Dissertação (Mestrado em Artes) - Instituto de Artes, Universidade Estadual de Campinas, 2014.

VOLÚSIA, Eros. Dansa Brasileira: a creação do bailado brasileiro. Rio de Janeiro: Typographia Baptista de Souza, 1939.

WILKINSON, Gary. Pedagogy of the Possessed: the privatization of civic education and values under New Labour. Educational Review, v. 59, n. 3, p. 267-284, 2007. 
E-ISSN 2237-2660

Ana Paula Höfling is Assistant Professor of Dance at the University of North Carolina, Greensboro. She holds a PhD from UCLA (University of California, Los Angeles), and was an Andrew W. Mellon Postdoctoral Fellow at Wesleyan University. Her research focuses on capoeira and Afro-Brazilian corporeality.

E-mail: aphofling@uncg.edu

This unpublished text, proofread by Ananyr Porto Fajardo, is also published in Portuguese in this issue.

Received in August 28, 2015 Accepted in January 25 $5^{\text {th }}, 2016$ 